\title{
IMPLEMENTASI KARAKTER PEDULI LINGKUNGAN DI SDN 13 LOLONG BELANTI PADANG
}

\author{
Nofriza Efendi1, Refli Surya Barkara ${ }^{2}$, Yanti Fitria ${ }^{3}$ \\ 1Pascasarjana Pendidikan Dasar, Universitas Negeri Padang \\ 2Program Studi Pendidikan Sejarah, UIN IB Padang \\ ${ }^{3}$ Pascasarjana Pendidikan Dasar, Universitas Negeri Padang \\ e-mail: nofrizaefendi94@gmail.com
}

\begin{abstract}
This study aims to analyze the implementation of the value of caring for the environment through learning in the classroom, the implementation of the value of caring for the environment through extracurricular activities and the obstacles found in the implementation of the value of caring for the environment in elementary schools. This type of research is a qualitative research with a case study approach. Informants are determined using Purposive Sampling. the research results obtained findings that (1) Internalization of the value of environmental care in learning planning in the form of compiling teaching devices such as syllabus, Learning Implementation Plan (RPP) and learning media, the device has been analyzed in advance about the value content contained in the material to be taught (2) Implementation of the value of environmental care is integrated through learning in the classroom and through routine school activities, spontaneous activities and through exemplary behavior (3) Obstacles found in the implementation of the value of environmental care consist of internal factors such as, bad habits of students do not care about personal hygiene, lack of knowledge students to choose the scattered garbage. External factors such as lack of adequate facilities and lack of collaboration between parents and teachers in schools.
\end{abstract}

Keywords: implementation, environmental care, elementary schools, character

\section{PENDAHULUAN}

Kondisi lingkungan global dewasa ini semakin memprihatinkan. Hal ini dipicu oleh ulah manusia yang mengeksploitasi sumber daya alam dan lingkungan tanpa batas. Globalisasi dan modernisasi telah mengubah struktur masyarakat Indonesia menjadi bangsa yang kehilangan jati diri dan kepribadiannya. Pada aspek sosial, jati diri bangsa Indonesia cenderung mengarah pada dimensi pragmatis dan materialistis daripada spiritual dan humanis. Sedangkan dari aspek pendidikan, generasi muda sekarang lebih dekat dengan kekerasan, individualis dan asosial (Susanto, 2013: 289).

Kesadaran manusia akan pentingnya menjaga lingkungan masih rendah. Banyak anak-anak, remaja bahkan orang dewasa yang masih terbiasa membuang sampah di sembarang tempat. Kesadaran tersebut harus ditanamkan dari usia sedini mungkin. Dengan adanya kebijakan pendidikan karakter di sekolah, kesadaran tersebut bisa terwujudkan (Rahman, 2013: 148).

Berkaitan dengan perilaku manusia terhadap kondisi sumber daya alam dan lingkungan yang cenderung tidak peduli, maka mengubah perilaku menjadi prioritas utama dalam mengatasi krisis lingkungan. Kepedulian terhadap peduli 
dan berbudaya lingkungan dapat dianggap sebagai suatu perhatian terhadap faktafakta dan perilaku dari diri sendiri dengan konsekuensi tertentu untuk menjaga lingkungan di sekitar kita (Stia, 2017:138). Oleh sebab itu pentingnya nilai peduli lingkungan perlu diimplementasikan kepada peserta didik.

Hal ini juga menjadi suatu gambaran bahwa perubahan perilaku manusia senantiasa membutuhkan edukasi untuk mengatasi permasalahan lingkungan yaitu melalui pembentukan karakter peduli lingkungan sejak dini. Proses penanaman dan kesadaran tentang pentingnya menjaga lingkungan sangat baik apabila mulai diterapkan melalui pendidikan.

Pendidikan karakter peduli pada lingkungan sudah ada di dalam kurikulum sekolah sejak dulu (Kholiftul, 2014: 39). Hal ini dapat dilihat dari tata ruang sekolah yang asri dan hijau. Tetapi konsep kepedulian lingkungan tersebut belum sepenuhnya diimplementasikan kehidupan sehari-hari di sekolah. Hal ini dapat dilihat dari beberapa anak yang masih mengabaikan tanaman di sekitarnya yang layu, membuang sampah tidak pada tempatnya, guru masih memiliki pemikiran bahwa media pembelajaran harus selalu baru, dan masih banyak lagi (Kholiftul, 2014: 39).

Pendidikan karakter sebaiknya ditanamkan sejak dini terutama pada sekolah dasar yang merupakan tempat pendidikan yang utama bagi anak. Banyak fenomena yang kurang pantas dilihat sebagai anak yang berpendidikan. Misalnya, seringkali kita mendengar slogan-slogan diberbagai tempat terutama di sekolah, yang isinya mengajak kita untuk menjaga kebersihan lingkungan, akan tetapi slogan tadi tidak kita pedulikan. Slogan tadi fungsinya hanya seperti hiasan belaka tanpa ada isinya, padahal isi dari sebuah slogan sangat penting bagi kita (Dwi, 2016: 117).

Dalam upaya membangun karakter peserta didik harus berinteraksi dengan lingkungan secara baik, karakter tidak berfungsi dalam ruang hampa, akan tetapi berfungsi dalam melestarikan lingkungan (Wuryadani, 2016) Sikap peduli dan berbudaya lingkungan merupakan tugas kita dalam menjaga lingkungan, manusia sebagai makhluk sosial harus mempunyai sikap berinteraksi dengan alam secara baik (Maunah, 2016)

Peduli lingkungan merupakan aspek-aspek berperan dalam mengkondisikan lingkungan sekolah untuk membiasakan perilaku peduli lingkungan peserta didik dan warga sekolah lainnya. Pembiasaan perilaku peduli lingkungan tersebut akan membentuk karakter peduli lingkungan peserta didik, dan peserta didik akan mempunyai kebiasaan untuk menjaga, merawat dan melestarikan lingkungannya (Muhammad, 2017: 4). Pembiasaan tersebut dilakukan dalam bentuk menjaga lingkungan tapi dapat menciptakan formulasi dalam mengurangi populasi sampah dengan menjadikan suatu karya dari sampah menjadi bahan yang bernilai ekonomi (Surya, 2015: 105).

Hasil temuan di atas dapat dijadikan rujukan dalam penelitian bahwa lingkungan yang sehat dan nyaman dapat meningkatkan prestasi dan kreativitas peserta didik. Sekolah merupakan salah satu tempat yang sangat berperan dalam menerapkan pendidikan karakter Upaya implementasi nilai karakter peduli lingkungan yang dapat diberikan kepada peserta didik di Sekolah Dasar berupa kegiatan sederhana di sekeliling kelas atau lingkungan kelas. Tindakan ini akan menjadi sebuah kebiasaan yang akan diterapkan peserta didik di dalam 
lingkungan sehari-hari berupa: (1) Perilaku membuang sampah pada tempatnya, (2) Buang Air besar dan kecil di toilet, (3) Peduli dengan tumbuhan yang berada di sekitar sekolah dengan melakukan perawatan dan tidak merusaknya, (4) Kegiatan piket harian juga menjadi sebuah kegiatan rutin siswa, (5) Mengingatkan orang sekitar untuk menjaga lingkungan (Amirul Mukminin, 2014: 5). Tindakan implementasi nilai karakter dapat terlaksana dengan baik apabila (1) Dilaksanakan melalui kegiatan rutin sekolah, (2) pelaksanaanya dilaksanakan secara spontan, (3) dengan menunjukan keteladanan, dan (4) mengkondisikan keadaan sekolah sesuai dengan karakter yang diterapkan (Surya, 2019: 250).

Berdasarkan observasi tanggal 7-10 Januari 2019, penulis menemukan beberapa perilaku peserta didik yang mencerminkan telah melaksanakan nilai peduli lingkungan berupa: (1) peserta didik membersihkan lapangan sekolah sebelum berbunyi lonceng masuk pelajaran, (2) sebelum memulai pembelajaran peserta didik melihat kondisi kebersihan di sekitar tempat duduk, (3) setiap pagi dan sebelum pulang sekolah peserta didik selalu menyirami taman bunga. Upaya dalam pembinaan nilai peduli lingkungan yaitu melalui kegiatan pembiasaanpembiasaan hal-hal yang kecil dalam menjaga kebersihan diri dan kebersihan lingkungan. Usaha yang dilakukan secara terus menerus (konsisten) dalam melaksanakan program inilah yang menjadi poin tambahan peserta didik sehingga memunculkan kesadaran diri untuk pentingnya menjaga lingkungan.

\section{METODE PENELITIAN}

Jenis Penelitian yang digunakan penelitian kualitatif dengn menggunakan pendekatan studi kasus (case study). Menurut Creswell (2010: 20) mengatakan bahwa studi kasus merupakan strategi peneliti untuk menyelidiki secara cermat suatu program, peristiwa, aktivitas, proses, atau sekelompok individu, beragam sumber informasi yang kaya akan konteks dilakukan untuk penggalian data.

Adapun penetapan informan penelitian dengan teknik Purposive Sampling. Informan diambil dari beberapa kriteria, di antaranya merupakan guru kelas, menerapkan nilai-nilai karakter peduli kebersihan pada pembelajaran di dalam kelas, dan menerapakan dalam silabus ataupun RPP.

Burhan bungin (2010: 105) mengatakan bahwa pengambilan informan secara Purposive Sampling (memilih dengan sengaja) yaitu menentukan informan dengan pertimbangan tertentu dipandang dapat memberikan data yang maksimal mengenai implementasi nilai peduli lingkungan di sekolah. Tempat penelitian berlokasi di SD Negeri 13 Lolong Belanti, Jalan Bayur Nomor 7 Lolong Belanti Kecamatan Padang Utara Kota Badang Provinsi Sumatera Utara.

Teknik pengumpulan data menggunakan observasi, pada tahap ini peneliti terlebih dahulu melakukan pengamatan agar lebih meyakinkan objek penelitian yang akan didalami. Wawancara mendalam dilakukan untuk menggali lebih dalam data-data agar lebih beragam dan terperinci dan jelas. Serta dokumentasi untuk mengumpulkan data-data pendukung agar lebih akurat dan terjamin keaslian data yang dikumpulkan. Adapun teknik analisis data yang digunakan berupa reduksi data, penyajian data dan penarikan kesimpulan data sebagaimana yang kerap dilakukan dalam penelitian kualitatif. 


\title{
HASIL DAN PEMBAHASAN
}

\section{Implementasi Nilai Peduli Lingkungan Melalui Pembelajaran dalam Kelas di SDN 13 Lolong Belanti Padang}

Internalisasi nilai karakter nilai peduli lingkungan tidak terlepas dari usaha guru dalam perencanaan pembelajaran. Hal ini disebabkan oleh satu elemen yang terpenting dalam menyusun rencana pembelajaran menunjukan kepada kemampuan professional seorang pendidik. Perencanaan adalah kegiatan guru dalam mempersiapkan keperluannya sebelum melaksanakan pembelajaran di kelas berupa menyusun perangkat pengajaran seperti silabus, Rencana Pelaksanaan Pembelajaran (RPP) dan media pembelajaran. Perangkat tersebut telah dianalisis terlebih dahulu oleh guru mengenai muatan nilai yang terkandung dalam materi yang akan diajarkan, untuk itu perlu disusun secara matang sebelum pelaksanaan pembelajaran di kelas.

Hal ini didukung oleh Kunandar (2011: 264) menjelaskan bahwa RPP merupakan persiapan yang harus dilakukan oleh seorang guru sebelum mengajar, hal ini bertujuan untuk: (1) Mempermudah, memperlancar dan meningkatkan hasil proses pembelajaran, (2) Menyusun rencana pembelajaran secara professional, dan sistematis, maka guru akan mampu melihat, mengamati, menganalisis, dan memprediksi program pembelajaran sebagai kerangka kerja yang logis dan terencana.

Dalam penyusuan RPP sangat penting memperhatikan tujuan dari materi yang dicapai, nilai karakter apa yang diinginkan dari materi tersebut sehingga dengan RPP akan tersampaikan tujuan dari penyampaian materi. Dalam perencanaan pembelajaran, guru menyiapkan perangkat pembelajaran berupa silabus dan RPP. Perangkat seperti silabus dan RPP telah dianalisis terlebih dahulu oleh guru kelas dan memasukan kemungkinan materi yang bisa diinternalisasikan dengan nilai karakter peduli lingkungan.

Jika teori tersebut dikaitkan dengan perencanaan yang telah disusun oleh ibu Okta Prima Sari, S.Pd guru kelas II dan ibu Rita Kurnia S.Pd guru kelas IV dalam menyiapkan pembelajaran sudah mengikuti langkah di atas dengan baik karena berdasarkan hasil wawancara dengan guru bersangkutan bahwa dia telah menyusun rencana pembelajaran sesuai prosedur yang telah ditetapkan sehubungan materi yang telah diajarkan.

\begin{abstract}
"Sebagai guru tentunya perlu dilakukan persiapan matang sebelum menghadapi murid. Salah satu yang terpenting adalah menyusun rencana pembelajaran sehingga ketika mengajar, sebagai guru tidak asal mengajar dan juga lebih terkonsep penyampaian pembelajaran kepada peserta didik. Selain itu, diperlukan inovasi dengan memberikan muatan peduli lingkungan pada pembelajaran yang sesuai deng hal tersebut" (Okta Prima Sari: Guru Kelas II SDN 13 Lolong Belanti Padang, 2019).
\end{abstract}

Sejalan dengan Okta Prima Sari, Okta Kurnia juga mengungkapkan bahwa setiap pembelajaran dengan peserta didik telah disiapkan secara terstruktur melalui perangkat pembelajaran berupa silabus dan RPP.

"Setiap pembelajaran dengan peserta didik telah disiapkan secara terstruktur melalui perangkat pembelajaran berupa silabus dan RPP. Terlebih dahulu saya analisis dan memasukan nilai karakter peduli lingkungan" (Rita Kurnia: Guru Kelas IV SDN 13 Lolong Belanti Padang, 2019). 
Nilai yang dilakukan dalam penelitian ini adalah nilai peduli lingkungan yang akan diimplementasikan melalui pelaksanaan pembelajaran. Menurut Hasan (2011: 35), Ada strategi yang dapat dilakukan untuk mengembangkan pendidikan karakter pembelajaran adalah Integrasi nilai pendidikan karakter dalam kurikulum. Pengintegrasian atau mungkin lebih tepat "alignment" adalah suatu proses memperkaya mata pelajaran atau sedang dilaksanakan dengan nilai dalam pendidikan karakter. Proses tersebut dilakukan melalui langkah-langkah berikut: (1) Memasukan nilai terpilih dari pendidikan karakter keterampilan dalam silabus, (2) Memasukan nilai pendidikan karakter dalam rencana pelaksanaan pembelajaran (RPP) yang dikembangkan, (3) Melaksanakan pembelajaran sesuai dengan RPP dengan memperhatikan proses pembelajaran untuk penguasaan keterampilan dan internalisasi nilai, (4) Melaksanakan penilaian hasil belajar.

Hal tersebut yang juga turut dilakukan oleh kedua informan dalam penelitian ini. Menurutnya, pengembangan nilai-nilai karakter kepada peserta didik dilakukan dengan internasilisasi nilai-nilai karakter dalam RPP dan silabus.

"Nilai pendidikan karakter itu penting, makanya sangat diperlukan dalam pembelajaran dalam kelas bagi peserta didik sehingga lebih memahami bagaimana pendidikan karakter dilakukan dalam kehidupan sehari-hari. Oelh karena itu memang saya memasukkan dalam silabus ataupun RPP" (Okta Prima Sari: Guru Kelas II SDN 13 Lolong Belanti Padang, 2019).

Sejalan dengan Okta Prima Sari, Okta Kurnia juga mengungkapkan bahwa setiap pembelajaran dengan peserta didik telah disiapkan secara terstruktur melalui perangkat pembelajaran berupa silabus dan RPP.

"Melaksanakan pembelajaran sesuai dengan RPP dengan memperhatikan proses pembelajaran untuk penguasaan keterampilan dan internalisasi nilai kepada peserta didik. Internaliasi nilai yang dimaksud seperti peduli lingkungan. Nilainilai tersebut tentunyaa akan memunculkan karakter yang baik bagi peserta didik" (Rita Kurnia: Guru Kelas IV SDN 13 Lolong Belanti Padang, 2019).

Teori tersebut sejalan dengan program yang dilaksanakan oleh SDN 13 Lolong Kota Padang. Guru kelas telah menyusun RPP berdasarkan nilai karakter yang terkandung di dalamnya kemudian dalam pelaksanaan pembelajaran guru mengimplementasikan kedalam materi pembelajaran, bahkan dengan menginternalisasikan nilai karakter peduli lingkungan mampu meningkatkan minat dan aktivitas siswa. Uno (2015: 147) dalam (Dwi, 2017: 5) menyatakan bahwa motivasi belajar siswa akan lebih bertambah ketika mengalami pembelajaran dengan memanfaatkan lingkungan yang berbeda dari biasanya.

Selanjutnya dipertegas oleh Asmani (2011:58) pendidikan karakter yang terpadu dalam pembelajaran merupakan pengenalan nilai-nilai, diperolehnya kesadaran akan pentingnya nilai-nilai dan di internalisasi nilai-nilai ke dalam tingkah laku peserta didik dalam kehidupan sehari-hari. Hal itu sejalan dalam temuan peneliti, bahwa dalam mengimplementasikan nilai karakter bangsa melalui pembelajaran dilakukan dengan cara mengintegrasikan kedalam berbagai peraturan dan kebiasaan yang harus dilakukan oleh para peserta didik. 
Senada dengan itu Seriwati Bukit dan Widyaswara Madya (2014: 11) mengatakan perencanaan dan pelaksanaan pendidikan peduli lingkungan dan karakter bangsa dilakukan oleh kepala sekolah, guru, tenaga kependidikan secara bersama-sama sebagai suatu komunitas pendidik dan diterapkan ke dalam kurikulum melalui hal-hal berikut ini:

a. Kegiatan rutin sekolah

Kegiatan rutin merupakan kegiatan yang dilakukan peserta didik secara terus menerus dan konsisten setiap saat. Berdasarkan penemuan di lapangan kegiatan rutin yang dilakukan sekolah adalah menilai kebersihan siswa, memperhatikan kebersihan kelas dan melaksanakan Gotong Royong bersama yang dilakukan pada hari kamis. Kegiatan ini didukung oleh para guru dan peserta didik sehingga setiap siswa yang melanggar atau tidak melaksnakan kegiatan rutin tersebut tanpa alasan yang jelas makan akan dikenakan sangsi.

Hadiah ataupun sanksi dilakukan secara berkelanjutan sehingga menjadi sebuah kebiasaan pada siswa. Jika seseorang membiasakan diri dengan berperilaku seperti yang diharapkan akan terbentuk perilaku tersebut. Misalnya, seseorang membiasakan jalan kaki di pagi hari, membiasakan datang di kantor tidak terlambat, seseorang tersebut akan terbiasa dan tidak terbebani dengan kegiatan tersebut (Suharjana, 2012: 194).

"Jumat bersih merupakan kegiatan rutin yang dilakukan di sekolah. Kami dan peserta didik dengan membersihkan sampah-sampah yang ada dan menata lingkungan sekolah. Hal tersebut menjadi bagian kerja sama dan contoh kepada peserta didik bahwa sampah bukanlah sesuatu yang perlu dihindari tetapi perlu dibersihkan" (Rita Kurnia: Guru Kelas IV SDN 13 Lolong Belanti Padang, 2019).

b. Kegiatan spontan

Kegiatan spontan yaitu kegiatan yang dilakukan secara spontan pada saat itu juga. Kegiatan dilakukan biasanya pada saat guru adanya perbuatan yang kurang baik dari peserta didik yang harus dikoreksi pada saat itu juga. Kegiatan spontan yang dilakukan dalam mengimplementasikan nilai peduli lingkungan terlihat katika ada peserta didik yang melanggar peraturan seperti membuang sampah dilapangan, maka disaat seperti itu guru memarahi dan menasehati peserta didik tersebut. Nilai karakter peduli lingkungan yang terkandung dalam kegiatan spontan ini efektif dapat membimbing peserta didik dalam menanamkan nilai karakter melalui pembiasaan.

Tidak hanya berupa hukuman, hadiah yang diberikan guru sangat memotivasi siswa Hadiah yang diberikan sekolah baru sebatas motivasi atau ucapan, sementara untuk hadiah hanya pada waktu kegiatan perlombaan saja. Hukuman yang diberikan sekolah berupa peringatan dan pemahaman, membersihkan kamar mandi, jika ada yang merusak fasilitas maupun lingkungan sekolah yang bersangkutan disuruh untuk mengganti. Karakter yang dikembangkan adalah peduli lingkungan dan tanggungjawab (Riamadhani, 2015: 8).

"Terkadang peserta didik spontan membuang sampah sembarangan, mungkin karena kebiasaan. Tetapi kami menegur dan menasehati serta memberikan contoh agar tidak lagi membuang sampah sembarangan. Mereka perlu diberi tahu bahwa lingkungan serta segala sesuatu yang ada dibumi ini perlu dijaga kebersihan dan kelestariannya agar lingkungan selalu sehat dan terjaga dari 
pencemaran" (Okta Prima Sari: Guru Kelas II SDN 13 Lolong Belanti Padang, 2019).

c. Keteladanan

Keteladanan adalah perilaku dan sikap guru dalam memberikan contoh terhadap tindakan-tindakan baik khususnya dalam menjaga lingkungan sekolah dan peduli terhadap lingkungan sekitar sehingga diharapkan menjadi panutan bagi peserta didik untuk mencontohnya. Perilaku tersebut merupakan upaya yang dilakukan guru dalam mengimplementasikan nilai karakter baik dalam pembelajaran maupun diluar pembelajaran.

"Cara terbaik untuk mengajari nilai karakter kepada peserta didik adalah dengan memberikan keteladanan atau contoh tindakan kepada mereka. Guru tidak boleh semena-mena hanya sekadar menyuruh peserta didik peduli lingkungan, tidak buang sampah sembarangan, dan sebagainya lalu guru tidak melakukannya. Penerapan nilai-nilai karakter kepada peserta didik bukanlah sebuah intervensi dan paksaan tetapi contoh kebaikan bagi mereka, dan guru wajib member contoh yang baik" (Rita Kurnia: Guru Kelas IV SDN 13 Lolong Belanti Padang, 2019).

Menumbuhkan perilaku peduli lingkungan (yang menjadi bagian dari nilai karakter peduli lingkungan) dapat pula diawali dengan peran guru dalam memberikan keteladanan, guru dapat mencontohkan langsung (1) cara membuang sampah dengan baik dengan memisahkan sampah organik dengan anorganik, (2) memelihara tanaman (tidak merusak tanaman), (3) cara menghemat air dengan mencontohkan menyiram tanaman (4) menanam pohon di sekitar sekolah yang bisa diaplikasikan peserta didik di sekitar rumah masing-masing peserta didik (Nisa, 2015: 9). Selain itu keteladanan dapat dietapkan melalui Guru memulai pembelajaran tepat waktu, selalu bersikap sopan dan santun, membuang sampah pada tempatnya, tidak merusak lingkungan dan selalu ikut serta dalam menjaga dan merawat lingkungan baik itu di kelas maupun di luar kelas (Rezkita, 2018: 330).

d. Pengkondisian

Untuk mendukung keterlaksanaan nilai peduli lingkungan maka sekolah harus dikondisikan sebagai pendukung kegiatan itu. Misalnya, dalam mengimplementasikan nilai karakter peduli lingkungan sekolah membuat taman sekolah tempat ini digunakan untuk merawat tanaman.

"Sangat perlu sarana sekolah seperti taman karena menjadi perangkat pembelajaran bagi peserta didik peduli terhadap lingkungan dengan cara merawat taman setiap harinya. Dengan adanya sarana tersebut, akan jadi kebiasaan rutin yang dilakukan peserta didik dan tentunya tidak perlu disuruh oleh guru lagi" (Okta Prima Sari: Guru Kelas II SDN 13 Lolong Belanti Padang, 2019). 


\section{Hambatan Implementasi Nilai Peduli Lingkungan di SDN Lolong Belanti Padang}

Beberapa faktor hambatan implementasi pendidikan karakter nilai peduli lingkungan yaitu:

a. Faktor Internal

Merupakan faktor yang dipengaruhi dari diri peserta didik sendiri. Adapun yang menjadi faktor internal dalam menghambat penanaman nilai peduli lingkungan yaitu:

1) Kebiasaan Buruk Peserta Didik Tidak Peduli Kebersihan Diri

Salah satu penyebab internal kurangnya kesadaran peserta didik dalam melaksanakan nilai peduli lingkungan yaitu kebiasaan diri peserta didik yang tidak peduli dengan kebersihan dirinya dan tidak peduli tentang alam sekitarnya. Perilaku ini dipengaruhi oleh pembinaan orang tua peserta didik, pada dasarnya orang tua peserta didik tidak memperhatikan akan kebersihan diri peserta didik sehingga berpengaruh pada perilaku peserta didik yang tidak peduli pada kebersihan alam.

"Iya, memang peduli kebersihan diri masih kurang pada kalanganpeserta didik. Makanya ini yang perlu jadi perhatian sehingga peserta didik menjadikan kebiasaan hidup bersih di mana saja mereka berada melalui pembelajaran di sekolah. Sebagai guru, hal tersebut juga merupakan tanggung jawab kami untuk membekali peserta didik nilai-nilai karakter yang baik dan membangun secara positif" (Okta Prima Sari: Guru Kelas II SDN 13 Lolong Belanti Padang, 2019).

2) Rendahnya Pengetahuan Peserta Didik untuk Memilih Sampah yang Berserakan

Buktinya masih ada peserta didik yang tidak memperhatikan tulisan bagian pemilihan sampah saat membuang sampah. Kendala tersebut menunjukkan bahwa pengetahuan peserta didik memang masih kurang. Sehingga perlu selalu diberikan informasi dan dibiasakan agar peserta didik paham dan mampu membuang sampah sesuai pemilihannya.

"Sampah masih jadi masalah di lingkungan sekitar, termasuk di sekolah. Peserta didik kadang masih kurang perhatian terhadap sampah yang ditemui di lingkungannya. Peserta didik juga belum mengerti betul jenis-jenis sampah sehingga walaupun membuang sampah, terkadang tidak memperhatikan sampah dibuang pada tempat yang sesuai jenisnya" (Rita Kurnia: Guru Kelas IV SDN 13 Lolong Belanti Padang, 2019).

b. Faktor eksternal

Merupakan faktor yang mempengaruhi penanaman nilai-nilai peduli lingkungan dari luar yaitu:

1) Kurangnya Fasilitas yang Memadai

Penggunaan fasilitas sekolah guna menunjang pelaksanaan pembelajaran di sekolah belum memadai seperti kurangnya persediaan tong sampah sesuai dengan jenis sampah. Oleh sebab itu pentingnya penyediaan karena akan akan mempengaruhi keinginan siswa untuk menjaga kebersihan.

"Tempat sampah perlu diperbanyak di setiap sisi sekolah sehingga peserta didik juga lebih enteng buang sampahnya. Terkadang ada rasa malas buang sampah 
karena tempat sampahnya yang kejauhan" (Okta Prima Sari: Guru Kelas II SDN 13 Lolong Belanti Padang, 2019).

2) Kurangnya Kerjasama Orang Tua dengan Guru Sekolah

Kurangnya kerjasama orang tua dalam pembinaan nilai peduli lingkungan menyebabkan kurang optimalnya kesadaran peserta didik terhadapa peduli lingkungan terlihat pada sebahagian orang tua juga tidak memperhatikan kebersihan diri dan kerapian anaknya seperti kuku tangan anak yang panjangpanjang, baju yang tidak digosok. Ini merupakan bentuk pengabaian orang tua terhadap peserta didik.

"Kerja sama yang baik akan melahirkan hasil yang baik. Jika guru dan orang tua dapat bekerja sama mendidik peserta didik dengan nilai-nilai karakter, maka peserta didik akan semakin dibiasakan akan hal tersebut. tidak hanya di sekolah tetapi juga di rumah mereka" (Rita Kurnia: Guru Kelas IV SDN 13 Lolong Belanti Padang, 2019).

Hal yang sangat terpenting dalam menanamkan nilai karakter peduli lingkungan yaitu adanya kerja sama antara skolah dengan orang tua. solusi yang dilakukan untuk mengatasi agar penanaman pendidikan karakter dapat tercapai secara maksmal, dibutuhkan kerja sama semua pihak. Tidak hanya pihak sekolah yang mengusahakan agar penanaman karakter dapat berjalan dengan maksimal (Wijanarti, 2019: 397)

\section{KESIMPULAN}

Berdasarkan hasil penelitian dan pembahasan, maka penelitian ini dapat disimpulkan bahwa internalisasi nilai karakter nilai peduli lingkungan tidak terlepas dari usaha guru dalam perencanaan pembelajaran berupa menyusun perangkat pengajaran seperti silabus, Rencana Pelaksanaan Pembelajaran (RPP) dan media pembelajaran, perangkat tersebut telah dianalisis terlebih dahulu oleh guru mengenai meuatan nilai yang terkandung dalam materi yang akan diajarkan. Implementasi nilai peduli lingkungan diintegrasikan melalui pembelajaran didalam kelas dan melaui kegiatan rutin sekolah seperti menilai kebersihan kelas, kebersihan siswa. Kegiatan spontan dilakukan dalam mengimplementasikan nilai peduli lingkungan terlihat katika ada siswa yang melanggar peraturan seperti membuang sampah dilapangan, maka disaat seperti itu guru memarahi dan menasehati. Dan keteladanan perilaku dan sikap guru dalam memberikan contoh terhadap tindakan-tindakan baik khususnya dalam menjaga ligkungan sekolah dan peduli terhadap lingkungan serta pengkondisian. Misalnya, dalam mengimplementasikan nilai peduli lingkungan sekolah membuat Taman Sekolah tempat ini digunakan untuk merawat tanaman. Hambatan yang ditemukan dalam implementasi pendidikan karakter nilai peduli lingkungan terdiri dari faktor internal seperti Kebiasaan buruk siswa tidak peduli kebersihan diri, Rendahnya pengetahuan siswa untuk memilih sampah yang berserakan. Faktor eksternal seperti Kurangnya fasilitas yang memadai dan Kurangnya kerjasama orang tua dengan guru sekolah.

Agar penanaman nilai peduli lingkungan dapat berjalan secara optimal maka perlu memberikan standar indikator ketercapaian nilai peduli lingkungan yang tegas. Guru hendaknya memberikan penilaian karakter secara objektif tidak 
dipengaruhi oleh hal-hal yang subjektivitas. Hendaknya guru mengkaitkan materi pembelajaran dengan hal-hal yang terjadi saat sekarang ini sehingga peserta didik dapat memahami pentingnya nilai peduli lingkungan. Hendaknya guru, sekolah, orang tua serta lingkungan ikut bekerja sama dalam penanaman nilai peduli lingkungankepada peserta didik. Hendaknya penanaman nilai peduli lingkungan dilaksanakan secara terus menerus sehingga menjadi sebuah pembiasaan dalam kehidupan peserta didik.

\section{DAFTAR PUSTAKA}

Asmani, Ja'mal Ma'mur. 2011. Buku Panduan Internalisasi Pendidikan Karakter di Sekolah. Yogyakarta: Diva Press.

Bukit, Seriwa dan Widyaswara Madya. 2014. Pendidikan Karakter. Makalah tidak diterbitkan, Balai Diklat Keagamaan. Medan.

Bungin, Burhan. 2010. Metode Penelitian Kualitatif. Jakarta: Rajawali Pers.

Creswell. 2010. Research Design. Pendekatan Kualitatif, Kuantitatif dan Mixed. Yogyakarta: PT. Pustaka Belajar.

Dwi, Sekar Ardianti, Savitri Wanabuliandari, dan Susilo Rahardjo. 2017. Peningkatan Perilaku Peduli Lingkungan Dan Tanggung Jawab Siswa Melalui Model Ejas Dengan Pendekatan Science Edutainment. Jurnal Ilmiah "Pendidikan Dasar", IV (1).

Hafida, Nur. 2018. Pembentukan Karakter Peduli dan Berbudaya Lingkungan bagi Peserta Didik di Madrasah melalui Program Adiwiyata. Jurnal FIKROTUNA: Jurnal Pendidikan dan Manajemen Islam, 8 (2).

Hamzah, A. 2016. Profil Pembelajaran Karakter di Sekolah Dasar. JINOTEP, (6), 302.

Hasan. 2011. Pendidikan Sejarah untuk Memperkuat Pendidikan Karakter. Makalah Dikemukakan pada Seminar Sejarah Nasional Himpunan Mahasiswa Sejarah, UNNES, 10 Nopember 2011.

Mukminin, Amirul Al-Anwari. 2014. Strategi Pembentukan Karakter Peduli Lingkungan Di Sekolah. Jurnal. TA'DIB, XIX, (02).

Nisa, Jakiatin. 2015. Outdoor Learning sebagai Metode Pembelajaran IPS dalam Menumbuhkan Karakter Peduli Lingkungan. Jurnal SOSIO DIDAKTIKA: Social Science Education Journal, 2 (1).

Wakhidah, Kholifatul. 2014. Pengaruh Penanaman Nilai-Nilai Konservasi terhadap Karakter Peduli pada Lingkungan Anak Usia Dini. Jurnal BELIA, 3 (2).

Kunandar. 2011. Guru Profesional: Implementasi Kurikulum Tingkat Satuan Pendidikan (KTSP) dan Sukses dalam Sertifikasi Guru. Jakarta: PT. Raja Grafindo Persada. 
Maunah, Binti. 2015. Implementasi Pendidikan Karakter dalam Pembentukan Kepribadian Holistik Siswa. Jurnal Pendidikan Karakter, V (1), 90-101.

Muhammad. 2017. Pelaksanaan Program Adiwiyata dalam Mendukung Pembentukan Karakter Peduli Lingkungan di SD Negeri 4 Pandeglang. Jurnal Pendidikan Geografi, 17, (1).

Rimadhani, Melia Trahati. 2015. Implementasi Pendidikan Karakter Peduli Lingkungan di Sekolah Dasar Negeri Tritih Wetan 05 Jeruklegi Cilacap. Jurnal Pendidikan Guru Sekolah Dasar, Edisi 12 Tahun ke IV.

Rahman, Arif Hikam. dkk. 2013. Pengembangan Game Edukasi Visual Novel Berbasis Pembangunan Karakter pada Materi Pelestarian Lingkungan. Jurnal Unnes Journal of Biology Education, 2 (2).

Rezkita, Shanta dan Kristi Wardani. 2018. Pengintegrasian Pendidikan Lingkungan Hidup Membentuk Karakter Peduli Lingkungan di Sekolah Dasar. Jurnal Trihayu: Jurnal Pendidikan Ke-SD-an, 4 (2).

Suharjana. 2012. Kebiasaan Berperilaku Hidup Sehat dan Nilai-nilai Pendidikan Karakter. Jurnal Pendidikan Karakter, II (2).

Surya, Refli Barkara, dan Sermal. 2019. Pendidikan Karakter dalam Pembelajaran Sejarah untuk Meningkatkan Sikap Nasionalisme Siswa SMA Kota Padang. Seminar Nasional Sejarah ke 4 Jurusan Pendidikan Sejarah Universitas Negeri Padang.

Susanto, Ermawan. 2013. Pembelajaran Pendidikan Jasmani Berbasis Karakter untuk Meningkatkan Nilai-nilai Afektif di Sekolah Dasar. Jurnal Pendidikan Karakter, III (3).

Stia, Ayu Rini dan I Putu Gde Sukaatmadja I Gst. Ayu Kt. Giantari. 2017. Pengaruh Pengetahuan Lingkungan dan Kepedulian Lingkungan terhadap Sikap dan Niat Produk Hijau "The Body Shop di Kota Denpasar". Jurnal Ekonomi Dan Bisnis Universitas Udayana, 6 (1), 137-166.

Wijanart, Wilis, I Nyoman Sudana Degeng dan Sri Untari. 2019. Problematika Pengintegrasian Penguatan Pendidikan Karakter pada Pembelajaran Tematik. Jurnal Pendidikan, 4 (3), 393-398.

Wuryandani, Wuri Fathurrohman dan Unik and Ambarwati. 2016. Implementasi Pendidikan Karakter Kemandirian di Muhammadiyah Boarding School. Cakrawala $\begin{array}{lll}\text { Pendidikan, XXXV (2), } & 208 .\end{array}$ http://dx.doi.org/http://dx.doi.org/10.21831/cp.v15i2.9882. 